\title{
Can HEXACO-PI-R Adequately Represent the Four-Factor Model of Psychopathy?
}

\author{
Janko Međedović \\ Institute of Criminological and Sociological Research, \\ Faculty of Media and Communications, Belgrade, Serbia
}

\begin{abstract}
Recently there have been attempts to measure psychopathy via existing personality inventories. The aim of the present research was to explore whether six-factors personality structure (measured by HEXACO-PI-R) can be used for the assessment of the psychopathy model consisted of four traits: interpersonal, affective, lifestyle and antisocial (measured by SRP-4). In Study 1 (402 community participants), the proxy measures of these traits were generated using the HEXACO-PI-R items. It showed that all the psychopathy traits except antisocial tendencies are adequately explained by HEXACO traits: all of the $R^{2} \mathrm{~S}$ were $>.50$. Proxy measures had satisfactory reliabilities (all Alphas $>.70$ ) and adequate correlations with the original psychopathy scales. In Study 2 (345 undergraduate students) and Study 3 (245 male convicts), the discriminative and external validity of the proxy measures is further demonstrated. The results of the present research showed that HEXACO-PI-R can be used to explore interpersonal, affective and lifestyle features of psychopathy, which can facilitate further research. However, the usage of the inventories which measure psychopathy directly is still preferable when possible.
\end{abstract}

Keywords: HEXACO-PI-R, four-factor model of psychopathy, assessment

\section{Psychopathy and its Operationalizations}

Psychopathy is defined as a set of traits depicting manipulative and deceitful behavior, affective callousness and shallowness, accompanied by low impulse control (Hare, 2003). Some psychopathy operationalizations add the fourth trait: antisocial and criminal behaivor (Hare \& Neumann, 2009). It seems that psychopathy is based on a core dual deficit which is expressed in lower ability to feel fear, guilt, and emotional empathy followed by a deficit in behavioral control (Fowles \& Dindo, 2006). These two deficits then facilitate the emergence of amoral and antisocial behavior. That is why psychopathy has been widely explored in forensic contexts, mostly in order to predict criminal recidivism (Salekin, 2008) or

Janko Međedović, Institute of Criminological and Sociological Research, Gračanička 18, 11000 Belgrade, Serbia. E-mail: janko.medjedovic@fmk.edu.rs 
the type of a criminal act (Porter, ten Brinke, \& Wilson, 2009). However, it is shown that psychopathy is useful for the explanation of various behaviors, including the ones outside forensic contexts, like workplace behavior (Mathieu \& Babiak, 2015), social interactions in friendships (Jonason \& Schmitt, 2012) or romantic partner relations (LeBreton, Baysinger, Abbey, \& Jacques-Tiura, 2013).

\section{Psychopathy and Personality}

Psychopathy is often portrayed as a psychopathological phenomenon, most frequently as a personality disorder (Miller, Lynam, Widiger, \& Leukefeld, 2001; Petrović \& Međedović, 2012). However, empirical research suggests that psychopathy is closely related to normal personality traits. Thus, psychopathy is described by lower Agreeableness and Conscientiousness from the Big Five / Five Factor Model of personality (Lynam, 2002). More precisely, psychopathy is related to the lack of altruism, compliance and straightforwardness, low deliberation and a sense of duty (Decuyper, De Pauw, de Fruyt, De Bolle, \& de Clercq, 2009).

Perhaps the highest potential for describing psychopathy has the six-factor model of personality, mostly because of the trait which is not depicted in other models: Honesty-Humility (Ashton \& Lee, 2008). Honesty factor depicts characteristics like integrity, honesty, sense of fair play, loyalty, and humility, while the attributes which lie on the opposite pole of the dimension are mischief, hypocrisy, arrogance, cunning, and greed (Lee \& Ashton, 2006). Probably the bestknown operationalization of the six-factor lexical model is HEXACO personality structure. It represents the acronym of the six broad and comprehensive traits: Honesty-Humility, Emotionality, Extraversion, Agreeableness, Conscientiousness, and Openness (Ashton et al., 2004). The research regarding the relations between HEXACO model and psychopathy showed that psychopathy can be described mostly by negative poles of Honesty, Emotionality, Agreeableness, and Conscientiousness factors (De Vries, Lee, \& Ashton, 2008; Međedović, 2011). This result implies that psychopathy is characterized by dishonesty, low sense of fair play, emotional coldness and detachment, antagonism, retaliation towards others and recklessness followed by impulsivity.

\section{Measuring Psychopathy via Existing Personality Inventories}

Previously described findings suggest that psychopathy can be viewed as a specific constellation of basic personality traits. Following this approach, many authors suggested that the inventories of general personality can be used for psychopathy measurement. The first research went in the direction of constructing the personality prototype which would correspond to psychopathy (Miller et al., 2001). This prototype was based on the Five Factor Model of personality and it was constructed by experts' ratings. Although the data showed that the prototype could be useful in psychopathy examination, it is determined that using the psychopathy 
scales derived from existing inventories is more successful as a proxy measure of psychopathy (Witt et al., 2010). This approach is simple, and it is based on finding the inventory items which substantially correlate with the target scales of psychopathy and using them to construct new scales. Besides the Five Factor Model, Multidimensional Personality Questionnaire was most frequently used to obtain the personality measures of psychopathy (Blonigen, Hicks, Krueger, Patrick, \& Iacono, 2006; Walton, Roberts, Krueger, Blonigen, \& Hicks, 2008). HEXACOPI-R, an instrument which operationalizes six-factor structure, was used only in one study so far (Witt, Donnellan, \& Blonigen, 2009). All the previous research showed that using the scales derived from general personality inventories can be fruitful in the exploration of psychopathy.

\section{Goals of the Present Study}

Although many of the operationalizations of psychopathy currently exist, the four-factor model is one of the most frequently used in the empirical research (Paulhus, Neumann, Hare, Williams, \& Hemphill, 2016). It is comprised of four traits: interpersonal, affective, lifestyle, and antisocial tendencies, thus mirroring the structure and content of a "gold standard" in the psychopathy research Psychopathy Checklist-Revised (Hare, 2003). However, so far there was no research aimed at exploring whether these four factors could be adequately represented by existing personality inventories. Among all the personality models, HEXACO structure could be especially useful for this exploration because the Honesty factor is shown to gather various amoral and antisocial traits on its negative pole (Međedović, 2012).

The aim of the present research is to evaluate if HEXACO-PI-R can validly and reliably represent the four-factor psychopathy model. In order to do so, we conducted three studies. The first one served to explore if HEXACO scales can explain the variance of the four psychopathy traits and to select the inventory items which would be used for the construction of the proxy psychopathy scales. The goal of two other studies was to explore the validity of new scales by using them in the prediction of the external criteria, conceptually related to psychopathy. Taken together, these three studies are based on the samples frequently used in the research which administrate self-report measures of psychopathy: community, college and the sample of offenders.

\section{Study 1}

The first study has had several goals: 1) to explore predictive power of HEXACO personality traits in regard to four psychopathy characteristics; 2) to identify HEXACO-PI-R items suitable for the proxy psychopathy scales; 3) to evaluate the reliabilities of these scales and their correlations with original 
psychopathy measures. Regarding the second goal, we used the similar procedure as the one conducted in the previous research (Witt et al., 2009). Correlations between the HEXACO-PI-R items and the original psychopathy measures were calculated. All items with the correlations higher than .20 were used for the construction of the proxy measures. The HEXACO items were not repeated in different psychopathy scales: one item was used as an indicator for one scale only. The relations between HEXACO items and four psychopathy scales were analyzed at the same time. By doing this we avoided a possible error of selecting the items for one scale and excluding them from the item pool. There were occasions where one HEXACO item had correlations with multiple psychopathy scales above 20 . However, these correlations were never of exactly the same effect size and we simply assigned the item to a scale with the highest correlation.

\section{Method}

\section{Sample}

The data was gathered via an online survey. Participants were selected from the community sample $\left(N=402 ; M_{\text {age }}=28.3, S D=6.96 ; M_{\text {education }}{ }^{*}=15.6, S D=3.31\right)$. Participants (70\% females) were recruited mostly on social networks using the snowball procedure. They received a feedback regarding their personality profile as a motivation for the participation in the study.

\section{Measures}

HEXACO-PI-R (Lee \& Ashton, 2006) was used for the exploration of the six lexical personality factors. Besides the six broad factors, the instrument measures 25 lower-order facet traits. It has 100 items and every facet is measured via 4 items. All the inventory items were included in the analysis (including the interstitial Altruism scale). The reliability of the facets ranged from $\alpha=.58$ (Anxiety) to $\alpha=.76$ (Fairness and Sociability).

Psychopathy was measured via SRP-4 scale (Self Report Psychopathy; Paulhus et al., 2016). Its structure consisted of four traits: interpersonal $(M=2.47$; $S D=0.54 ; \alpha=.78)$, affective $(M=2.07 ; S D=0.45 ; \alpha=.70)$, lifestyle $(M=2.49 ; S D=0.55$; $\alpha=.73)$, and antisocial $(M=1.50 ; S D=0.49 ; \alpha=.72)$. The inventory has 64 items, 16 per each trait.

All of the measures are self-report inventories. Both inventories have 5-point response scale, where 1 stands for "strongly disagree with the statement" and 5 for

\footnotetext{
${ }^{*}$ years of formal schooling
} 
"strongly agree with the statement". There were no missing values since all of the items were mandatory.

\section{Results}

\section{Constructing the HEXACO-PI-R Psychopathy Scales}

When Interpersonal psychopathy scale was regressed onto HEXACO facets, a significant regression function was obtained. The coefficient of multiple correlation between personality and the criterion measure was high enough $\left[R=.72 ; R^{2}=.52\right.$; $F(25,379)=16.06, p<.01]$ to proceed to analyze the correlations between the personality items and Interpersonal scale. The total number of 18 items was found to have correlations higher than .20 with the criterion. When they were used to predict the target measure, again the high percentage of psychopathy trait was predicted $\left[R=.71 ; R^{2}=.50 ; F(18,386)=18.28, p<.01\right]$. These items were used for the construction of the HEXACO Interpersonal scale ${ }^{1}$.

Similar results were obtained when Affective psychopathy scale was set as a criterion measure. HEXACO facets explained substantial portion of the criterion's variance $\left[R=.71 ; R^{2}=.51 ; F(25,379)=15.55, p<.01\right]$ and again 18 items were chosen for the construction of the new scale. They successfully explained the original Affective scale variance $\left[R=.74 ; R^{2}=.54 ; F(18,386)=25.27, p<.01\right]$.

More than a half of the psychopathic Lifestyle variance was explained by HEXACO facets too $\left[R=.71 ; R^{2}=.51 ; F(25,379)=15.28, p<.01\right]$. The new scale of Lifestyle was constructed by 17 HEXACO items. When the original scale is regressed onto these items, a significant regression function is obtained: $R=.74$; $R^{2}=.55 ; F(17,387)=27.18, p<.01$.

However, when Antisocial tendencies were set as a target measure, HEXACO facets explained substantially lower percentage of its variance: $R=.42 ; R^{2}=.18$; $F(25,379)=3.22, p<.01$. When we analyzed the correlations between HEXACO items and this criterion measure, we did not find any coefficient higher than .20 . Since this was the only psychopathy scale which was negatively skewed in the present sample (Kolmogorov-Smirnov $Z=3.29 ; p<.01$ ), we normalized it by using the Bloom's algorithm and repeated the analyses with the normalized measure as a criterion. However, the results were almost exactly the same as in previous analysis: $R=.43 ; R^{2}=.19 ; F(25,379)=3.49, p<.01$. These results suggested that HEXACO items could not be used to construct a proxy measure of Antisocial characteristics.

\footnotetext{
${ }^{1}$ All of the HEXACO-PI-R items used for the construction of the psychopathy scales can be seen in the Appendix.
} 


\section{Descriptive Statistics and Validity of the New Psychopathy Scales}

First we calculated the descriptive statistics and the coefficients of internal consistency (Cronbach's $\alpha$ ) for the new psychopathy scales. The results of these analyses are shown in Table 1.

Table 1. Descriptive Statistics and the Reliabilities of the HEXACO Psychopathy Scales

\begin{tabular}{lcccccc}
\hline & $M$ & $S D$ & Skewness & Kurtosis & $K-S z$ & $\alpha$ \\
\hline HEXACO Interpersonal & 2.76 & 0.47 & 0.04 & 0.02 & $0.71 \mathrm{~ns}$ & .77 \\
HEXACO Affective & 2.43 & 0.49 & 0.37 & 1.16 & $0.72 \mathrm{~ns}$ & .75 \\
HEXACO Lifestyle & 2.59 & 0.54 & 0.34 & 0.40 & $0.90 \mathrm{~ns}$ & .77 \\
\hline
\end{tabular}

Notes. $K-S z$ - Kolmogorov-Smirnov $z$ statistic; $n s$ - not significant

As it can be seen from the Table 1, the reliabilities of the new scales are all higher than .70. Perhaps it could be argued that these reliabilities are not so high if we keep in mind that the new scales are consisted of 17 and 18 items per scale. That is why we performed the item-level analysis in order to examine if there are some items which could be excluded from the scales. However, this analysis showed that reliability could not be substantially elevated by the exclusion of some items: the range of reliability increase was from .01 to .03 . It is also interesting that all of the new scales have normal distributions in the sample. This finding suggests that the HEXACO psychopathy scales adequately capture the individual differences of these constructs in a community sample.

The key test for the validity of proxy psychopathy measures are the correlations with the original, SRP-4 scales. We calculated the Pearson's correlation coefficients between new and the original psychopathy measures. Furthermore, we provided the correlations between the original HEXACO personality traits and SRP-4 psychopathy measures as well. The rationale behind this is to compare the strength of associations between new psychopathy measures and the HEXACO traits with the original scales. If the correlations between the new measures and SRP-4 scales are higher than the ones between HEXACO traits and SRP-4 scales, it would be an additional argument for the usage of new psychopathy measures. The results of the correlation analysis are shown in Table 2. 
Table 2. Correlations between the HEXACO and SRP-4 Psychopathy Scales

\begin{tabular}{lcccc}
\hline & $\begin{array}{c}\text { SRP } \\
\text { Interpersonal }\end{array}$ & $\begin{array}{c}\text { SRP } \\
\text { Affective }\end{array}$ & $\begin{array}{c}\text { SRP } \\
\text { Lifestyle }\end{array}$ & $\begin{array}{c}\text { SRP } \\
\text { Antisocial }\end{array}$ \\
\hline Honesty-Humility & $-.50^{* * *}$ & $-.27^{* *}$ & $-.24^{* *}$ & $-.16^{* *}$ \\
Emotionality & $-.25^{* *}$ & $-.40^{* *}$ & $-.26^{* *}$ & $-.13^{* *}$ \\
Extraversion & $-.14^{* *}$ & $-.26^{* *}$ & -.04 & -.06 \\
Agreeableness & $-.45^{* *}$ & $-.29^{* *}$ & $-.22^{* *}$ & .02 \\
Conscientiousness & $-.13^{* *}$ & $-.11^{*}$ & $-.43^{* *}$ & $-.17^{* *}$ \\
Openness & $-.18^{* *}$ & $-.14^{* *}$ & .02 & -.10 \\
HEXACO Interpersonal & $.63^{* *}$ & $.37^{* *}$ & $.36^{* *}$ & $.14^{* *}$ \\
HEXACO Affective & $.41^{* *}$ & $.66^{* *}$ & $.25^{* *}$ & $.15^{* *}$ \\
HEXACO Lifestyle & $.36^{* *}$ & $.30^{* *}$ & $.68^{* *}$ & $.24^{* *}$ \\
\hline
\end{tabular}

Notes. SRP - Self Report Psychopathy; ${ }^{*} p<.05 ;{ }^{* *} p<.01$.

Correlation matrix is consisted of positive and significant coefficients, as expected. It can be seen that the relations between the scales with the same object of measurement are especially high in magnitude. Three new measures correlate with the SRP-4 Antisocial scale, however, these associations have low effect size. It should be noted that the strength of the associations between new measures and SRP-4 scales is indeed higher than any association between HEXACO traits and original psychopathy scales.

\section{Discussion}

The main finding of the first study is that HEXACO-PI-R items can adequately represent three of four Self-Report Psychopathy scales. The high proportion of Interpersonal, Affective, and Lifestyle variance is explained both by HEXACO facets and the items of the new scales. Multiple correlation coefficients between personality traits and psychopathy are similar to the ones obtained in previous attempts to measure psychopathy by existing personality inventories (Blonigen et al., 2006; Walton et al., 2008; Witt et al., 2009, 2010). Furthermore, the correlations between the new and the original psychopathy scales are almost of the same magnitude as in previous research (Witt et al., 2009). Three new scales have satisfactory reliabilities too. In fact, the reliabilities could not be substantially elevated by the exclusion of some items from the scales. We believe that this is due to the high representativeness of the HEXACO psychopathy scales. All the new measures are composed of the items belonging to different broad personality traits. This enables the comprehensiveness of the new scales. However, it keeps reliability coefficients at certain magnitude: the measures with broad and comprehensive content can never have very high $\alpha$ reliabilities. It is important to notice that the reliabilities are certainly high enough to provide reliable measurement, while high content broadness can elevate the quality of measurement as well. Keeping in mind that the distributions of new measures are normal and that they have higher 
correlations with original psychopathy scales than HEXACO personality traits, we can conclude that the HEXACO scales of Interpersonal, Affective, and Lifestyle psychopathy traits are valid and reliable measures.

However, the fourth trait cannot be operationalized by HEXACO-PI-R items. The variance of antisocial behavior explained by HEXACO facets is significantly lower, compared to the other three scales. This was not unexpected: previous research also showed that the predictive power of HEXACO factors was the lowest when this psychopathy trait was predicted (Međedović, 2011). Since none of the personality items had large enough correlations with the antisocial scale, we could not construct the new scale using HEXACO-PI-R items. This finding suggests that the inventories of broad personality traits have their limitations when some specific forms of psychopathic behavior are measured.

\section{Study 2}

The second study was aimed at further demonstrating the validity of HEXACO psychopathy scales. Three criterion measures were chosen in order to explore their relations with the new scales. The first is Manipulativeness, a facet of broad personality trait Negative Valence (Smederevac, Mitrović, \& Čolović, 2010). The second one is a trait depicting affective disturbances of a pro-psychotic type, expressed as inability to react emotionally to life events (Raine, 1991), labeled as Flattened Affect (Knežević, Opačić, Kutlešić, \& Savić, 2005). Finally, the third criterion measure is Impulsivity, the personality characteristic marked by lack of behavioral control and inability to delay gratification (Knežević, 2003). These three measures should have clear relations with psychopathic characteristics so we made these hypotheses: Interpersonal psychopathy features should be the best predictor of Manipulativeness; Affective trait should have the highest association with Flat Affect and Lifestyle characteristics should be the most important in the explanation of Impulsivity's variance.

\section{Sample}

Participants in this study were selected from the population of psychology undergraduate students, mostly freshmen $\left(N=365,65 \%\right.$ females; $\left.M_{\text {age }}=21, S D=3.9\right)$. All subjects participated voluntarily in the research. They were awarded by additional credits on the psychology course they attended. 


\section{Measures}

We used HEXACO-PI-R to calculate the scores on Interpersonal $(M=2.77$; $S D=0.51 ; \alpha=.78)$, Affective $(M=2.55 ; S D=0.49 ; \alpha=.73)$, and Lifestyle $(M=2.65$; $S D=0.55 ; \alpha=.77)$ psychopathic characteristics.

The scale for Manipulativeness assessment was taken from Big Five Plus Two personality inventory (Smederevac et al., 2010). The scale consists of 12 items $(M=1.83 ; S D=0.62 ; \alpha=.85)$.

The Flattened Affect scale was taken from DELTA 10 inventory, constructed for the examination of schizotypal features (Knežević et al., 2005). It has 8 items $(M=2.24 ; S D=0.52 ; \alpha=.71)$.

Impulsivity was explored via the same-labeled scale from AMORAL 9 inventory (Knežević, Radović, \& Peruničić, 2008). It has 6 items $(M=2.50$; $S D=0.72 ; \alpha=.71)$.

All of the measures are self-report inventories. They have 5-point response scale, where 1 stands for "strongly disagree" and 5 for "strongly agree". Data gathering lasted for 30 minutes on average.

\section{Results}

\section{Prediction of the Criteria Measures by HEXACO Psychopathy Scales}

In order to examine the predictive power of the HEXACO psychopathy scales, we set three regression models. Manipulativeness, Flat Affect, and Impulsivity were set as criteria measures, while the psychopathy characteristics were entered as predictors. Participants' sex was controlled in the analyses also. The results of the regression analysis are shown in Table 3.

Table 3. The Prediction of Manipulativeness, Flattened Affect, and Impulsivity

\begin{tabular}{lcccccc}
\hline & \multicolumn{2}{c}{ Manipulativeness } & \multicolumn{2}{c}{ Flattened Affect } & \multicolumn{2}{c}{ Impulsivity } \\
\cline { 2 - 7 } & $\beta$ & $r$ & $\beta$ & $r$ & $\beta$ & $r$ \\
\hline sex & -.02 & -.10 & $.18^{* * *}$ & -.01 & $.14^{* *}$ & .10 \\
HEXACO Interpersonal & $.51^{* *}$ & $.59^{* *}$ & $.17^{* *}$ & $.35^{* *}$ & $.14^{* *}$ & $.40^{* *}$ \\
HEXACO Affective & .09 & $.20^{* *}$ & $.36^{* *}$ & $.38^{* *}$ & -.04 & .06 \\
HEXACO Lifestyle & $.15^{* *}$ & $.39^{* *}$ & $.34^{* *}$ & $.48^{* *}$ & $.63^{* *}$ & $.68^{* *}$ \\
$F(4,361)$ & $45.73^{* *}$ & & $43.19^{* *}$ & & $75.99^{* *}$ & \\
$R^{2}$ & .38 & & .36 & & .50 & \\
\hline${ }^{* *} p<.01$. & \multicolumn{7}{c}{} & & &
\end{tabular}

All three regression functions were statistically significant $(p<.01)$. Interpersonal features had the highest predictive power when Manipulativeness was 
set as a criterion. The same could be said for Lifestyle characteristics in regard to Impulsivity trait. Lifestyle psychopathic characteristics had the highest zero-order correlation in the prediction of the Flat Affect too. However, when other psychopathy traits were controlled in the analysis, the predictive power of Lifestyle and Affective traits were almost the same.

\section{Discussion}

Two of the hypotheses regarding this study were fully confirmed. Interpersonal psychopathy features were the best predictor of Manipulativeness. This result is in line with the basic conceptualization of this psychopathy trait because manipulative and deceitful behavior represents a crucial part of interpersonal relations in psychopathy (Hare, 2003; Paulhus et al., 2016). The similar could be said for the psychopathic Lifestyle characteristics: they are highly related to low impulse control and lack of ability to delay gratification. The only hypothesis that was not confirmed completely is the one regarding the Flat Affect. All three psychopathy measures had independent contribution to the prediction of this criterion measure, with Affective and Lifestyle characteristics as dominant predictors. This result implies that callous and shallow psychopathic affectivity shares some characteristics with schizotypal flattened emotional reactions; however, they probably represent distinct emotional characteristics. This was already assumed by some researchers (Međedović, 2015). The exact nature of the relation between these two traits represents an interesting research goal per se, and it would be fruitful if future studies explored this topic in more detail.

\section{Study 3}

Psychopathy is a set of traits which are frequently explored in criminological and forensic contexts. This is why we analyzed the relations of new psychopathy scales with relevant outcomes on the sample of convicts in Study 3. Three criterion measures which can be plausibly related to narrow psychopathy traits are chosen in this study, too. The first one is Machiavellianism. This trait depicts an attitude of reaching a goal at all costs, even if it implies hurting others (Christie \& Geis, 1970). The second one is subclinical sadism. It represents a tendency to feel positive emotions as a reaction to a distress of others (Buckels, Jones, \& Paulhus, 2013). Finally, the relations between psychopathy and criminal recidivism are explored since this behavior is very important in legal and criminological contexts. Three hypotheses are set: Machiavellianism should be related mostly to Interpersonal psychopathy traits; Lifestyle is supposed to be the best predictor of criminal recidivism; the correlations between sadism and all three psychopathy traits are expected. 


\section{Method}

\section{Sample}

This study included 220 male convicts who served their sentence in two penitentiary institutions at the time of data gathering $\left(M_{\text {age }}=32\right.$ years, $S D=10.51$; $M_{\text {education }}{ }^{*}=11.6, S D=2.36$ ). All subjects participated in the study on a voluntary basis. They had elementary reading skills at least. The majority of the participants $(51.6 \%)$ were sentenced for criminal acts which involved violence (murder and attempted murder, robbery with the usage of violence, grievous bodily harm, etc.) while the rest of them committed crimes such as robbery, unauthorized production, possession, and distribution of narcotic substances, fraud, etc. Most of the participants $(59.7 \%)$ were serving 1-5 years of prison sentence and had previous convictions $(78 \%)$.

\section{Measures}

Psychopathy traits were measured in the same manner as in previous studies. HEXACO-PI-R was used to calculate the scores on Interpersonal $(M=2.87$; $S D=0.55 ; \alpha=.72)$, Affective $(M=2.74 ; S D=0.46 ; \alpha=.67)$, and Lifestyle $(M=2.63$; $S D=0.51 ; \alpha=.69)$ traits.

Sadism and Machiavellianism were measured by AMORAL 9 inventory. Sadism has $5(M=1.96 ; S D=0.77 ; \alpha=.65)$ and Machiavellianism $(M=3.27 ; S D=1.05$; $\alpha=.71)$ is consisted of 4 items.

Criminal recidivism was measured by the data extracted from the participants' penitentiary files. Three indicators were used to calculate recidivism measure: the number of offenses, lawful sentences, and the number of terms served in prison. In order to calculate a singular recidivism measure, these indicators were subjected to Principal component analysis. One latent component is obtained (eigenvalue $=2.42$; $80.64 \%$ of original indicators variance is explained). All three indicators had high loadings on the component: number of offences (.89), sentences (.94) and the prison terms (.86). Participants' scores on this component are saved in the database (regression method) as a separate variable.

\footnotetext{
* years of formal schooling
} 


\section{Results}

\section{Prediction of the Criteria Measures by HEXACO Psychopathy Scales}

In order to evaluate the predictive abilities of the psychopathy scales, three regression models were set. Machiavellianism, sadism and criminal recidivism were set as criterion measures, while psychopathy traits were entered as predictor variables. Participants' age and education were controlled in the models, too. The results of the regression analyses are shown in Table 4.

Table 4. The Prediction of Machiavellianism, Sadism, and Criminal Recidivism

\begin{tabular}{lcccccc}
\hline & \multicolumn{2}{c}{ Machiavellianism } & \multicolumn{2}{c}{ Sadism } & \multicolumn{2}{c}{ Criminal } \\
& $\beta$ & $r$ & $\beta$ & $r$ & $\beta$ & $r$ \\
\hline age & -.08 & $-.22^{* *}$ & -.04 & $-.18^{*}$ & .08 & .03 \\
education & -.10 & -.14 & $-.15^{* *}$ & $-.19^{*}$ & -.09 & -.09 \\
HEXACO Interpersonal & $.32^{* *}$ & $.47^{* *}$ & $.15^{*}$ & $.40^{* *}$ & .01 & .12 \\
HEXACO Affective & .10 & $.25^{* *}$ & $.32^{* *}$ & $.44^{* *}$ & .05 & .10 \\
HEXACO Lifestyle & $.21^{* *}$ & $.42^{* *}$ & $.26^{* *}$ & $.44^{* *}$ & $.22^{* *}$ & $.23^{* *}$ \\
$F(5,215)$ & $15.51^{* *}$ & & $25.38^{* *}$ & & $2.32^{*}$ & \\
$R^{2}$ & .29 & & .35 & & .07 & \\
\hline
\end{tabular}

${ }^{*} p<.05 ;{ }^{* *} p<.01$.

As it can be seen from the Table 4, all of the regression models were statistically significant. However, the percentage of the criterions explained variance is quite different: the highest percentage of sadism's variance is explained (35\%), followed by Machiavellianism (29\%) and criminal recidivism (7\%). Interpersonal and Lifestyle traits were the most important predictors when Machiavellianism was set as the criterion measure; all three traits independently predicted sadism, while psychopathic Lifestyle was the only significant predictor of criminal recidivism.

\section{Discussion}

All of the hypotheses of the Study 3 were confirmed in the regression analyses. Previous research showed significant relations between psychopathy and Machiavellianism, with the associations between Interpersonal psychopathy traits and Machiavellian tendencies showing the highest magnitude (Međedović \& Petrović, 2015). This finding suggests that Interpersonal behavior specific to psychopathy is characterized by unscrupulous goal achieving, with employing deceitful and manipulative tactics. Earlier studies also found the relations between psychopathy and sadism, suggesting that these traits are similar but not the same (Mokros, Osterheider, Hucker, \& Nitschke, 2011). It can be noted that among all 
the psychopathy traits, Affective features show the highest associations with sadism. This finding is in line with the previous data of shared emotional empathy deficits between these two traits (O'Meara, Davies, \& Hammond, 2011). Finally, previous research also suggested that behavioral psychopathy traits, including the erratic and impulsive lifestyle, is the best predictor of criminal behavior (Leistico, Salekin, DeCoster, \& Rogers, 2008). This finding implies that individuals who more frequently commit crimes do so partly because they have problems in behavioral control and recklessness.

\section{General Discussion}

The results of present research suggest that HEXACO-PI-R items can adequately represent three of four psychopathy traits from the four-factor psychopathy model (Hare, 2003; Paulhus et al., 2016). HEXACO psychopathy scales cannot be treated as direct measures of psychopathy, but rather as indirect or proxy psychopathy scales. So why should researchers use indirect instead of direct psychopathy measures? There are several reasons for this. Surveys are frequently limited by the number of variables which can be administrated. Measuring psychopathy by existing personality scales can help researchers to cut down the number of items in a survey. Secondly, the SRP-4 scale of psychopathy is copyrighted measure, so researchers must pay if they want to use this scale. This can be troublesome, especially for the researchers with low funding. These problems with existing psychopathy measures are recognized in a scientific community (Witt et al., 2009), and they are a part of the motivation for doing the present research.

HEXACO facets did not explain large enough portion of the Antisocial psychopathy scale variance, nor there were correlations $>.20$ between HEXACOPI-R items and this measure. Therefore, we did not construct HEXACO measure of this variable. Is this a huge problem for the researchers who would like to operationalize four-factor model of psychopathy via HEXACO-PI-R? There is an ongoing debate regarding the conceptual status of antisocial behavior as a core psychopathy characteristic (Skeem \& Cooke, 2010). The constructors of the fourfactor model strongly advocate that antisocial tendencies are the crucial part of the psychopathy construct (Hare \& Neumann, 2010; Neumann, Hare, \& Pardini, 2015); however, this opinion is highly criticized and challenged (Cooke \& Michie, 2001; Cooke, Michie, \& Skeem, 2007; Međedović, Petrović, Kujačić, ŽeleskovĐorić, \& Savić, 2015). Furthermore, all of the contemporary models of psychopathy do not incorporate antisocial behavior as its crucial trait (Benning, Patrick, Hicks, Blonigen, \& Krueger, 2003; Boduszek, Debowska, Dhingra, \& DeLisi, 2016; Patrick, Fowles, \& Krueger, 2009). There are pragmatic reasons for not measuring antisocial behavior as a psychopathy trait too. The most important one refers to the forensic context which is highly relevant for psychopathy research. 
It considers predicting criminal recidivism by using psychopathy traits as predictors. If antisocial behavior is set as a predictor of recidivism, the regression model would be tautological: criminal behavior would be predicted by criminal behavior (Međedović, 2015). For all of these reasons, we think that inability of constructing HEXACO measure of antisocial behavior should not divert researchers from using HEXACO psychopathy scales in their research.

However, researchers should use the original psychopathy scales in the research whenever it is possible. The correlations between HEXACO measures and the original scales are ranging from .60 to .70. The correlations of the same magnitude between indirect and direct measures of psychopathy were obtained in previous research, too (Witt et al., 2009). This finding suggests that proxy measures and original scales are very similar, but not identical constructs. Furthermore, in order to obtain maximum validity, the specific psychopathy items, which are not present in broad and general personality inventories should be administrated. These are the reasons why original psychopathy measures should be used if psychopathy is the central construct of the research or when time constraints are not too high and larger surveys can be administrated.

The limitation of the present study lies in the fact that the sample of participants who provided the measures on HEXACO and psychopathy was not representative. This fact can diminish the usage of the scales in some specific samples, including the participants with lower educational level. Because of this, it is important to validate new psychopathy scales in different samples and to carefully examine their properties, both on the full scale and the item level. Certainly, the best validation for the HEXACO psychopathy scales would be the prediction of real behavior, especially the one conceptually related to psychopathy: immoral and antisocial behavior.

\section{References}

Ashton, M.C., \& Lee, K. (2008). The HEXACO model of personality structure and the importance of the $\mathrm{H}$ factor. Social and Personality Psychology Compass, 2, 19521962.

Ashton, M.C., Lee, K., Perugini, M., Szarota, P., de Vries, R.E., Di Blas, L., Boies, K., \& De Raad, B. (2004). A six-factor structure of personality-descriptive adjectives: Solutions from psycholexical studies in seven languages. Journal of Personality and Social Psychology, 86, 356-366.

Benning, S.D., Patrick, C.J., Hicks, B.M., Blonigen, D.M., \& Krueger, R.F. (2003). Factor structure of the Psychopathic Personality Inventory: Validity and implications for clinical assessment. Psychological Assessment, 15, 340-350. 
Blonigen, D.M., Hicks, B.M., Krueger, R.F., Patrick, C.J., \& Iacono, W.G. (2006). Continuity and change in psychopathic traits as measured via normal-range personality: A longitudinal-biometric study. Journal of Abnormal Psychology, 115, 85-95.

Boduszek, D., Debowska, A., Dhingra, K., \& DeLisi, M. (2016). Introduction and validation of Psychopathic Personality Traits Scale (PPTS) in a large prison sample. Journal of Criminal Justice, 46, 9-17.

Buckels, E.E., Jones, D.N., \& Paulhus, D.L. (2013). Behavioral confirmation of everyday sadism. Psychological Science, 24, 2201-2209.

Christie, R.C., \& Geis, F.L. (1970). Studies in Machiavellianism. New York: Academic Press.

Cooke, D.J., \& Michie, C. (2001). Refining the construct of psychopathy: Towards a hierarchical model. Psychological Assessment, 13, 171-188.

Cooke, D.J., Michie, C., \& Skeem, J. (2007). Understanding the structure of Psychopathy Checklist-Revised. The British Journal of Psychiatry, 190, 39-50.

Decuyper, M., De Pauw, S., de Fruyt, F., De Bolle, M., \& de Clercq, B.J. (2009). A metaanalysis of psychopathy, antisocial PD and FFM associations. European Journal of Personality, 23, 531-565.

De Vries, R.E., Lee, K., \& Ashton, M.C. (2008). The Dutch HEXACO Personality Inventory: Psychometric properties, self-other agreement, and relations with psychopathy among low and high acquaintanceship dyads. Journal of Personality Assessment, 90, 142-151.

Hare, R.D. (2003). The Hare Psychopathy Checklist-Revised (2nd ed.). Toronto: MultiHealth Systems.

Hare, R.D., \& Neumann, C.S. (2009). Psychopathy and its measurement. In P.J. Corr \& G. Matthews (Eds.), Cambridge handbook of personality psychology (pp. 660-686). Cambridge: Cambridge University Press.

Hare, R.D., \& Neumann, C.S. (2010). The role of antisociality in the psychopathy construct: Comment on Skeem and Cooke (2010). Psychological Assessment, 22, 446-454.

Fowles, D.C., \& Dindo, L. (2006). A dual deficit model of psychopathy. In C.J. Patrick (Ed.), Handbook of psychopathy (pp. 14-34). New York: Guilford Press.

Jonason, P.K., \& Schmitt, D.P. (2012). What have you done for me lately? Friendshipselection in the shadows of Dark Triad traits. Evolutionary Psychology, 10, 400-421.

Knežević, G. (2003). Koreni amoralnosti. Institut za kriminološka i sociološka istraživanja, Beograd: Institut za psihologiju.

Knežević, G., Opačić, G., Kutlešić, V., \& Savić, D. (2005). Preserving psychoticism as a basic personality trait: A proposed reconceptualization. 113th Annual Convention. American Psychological Association, Washington. Book of Abstracts, p. 176. 
Knežević G., Radović, B., \& Peruničić, I. (2008). Can amorality be measured? $14^{\text {th }}$ European Conference on Personality, Tartu, Estonia. Book of Abstracts, p. 137.

LeBreton, J.M., Baysinger, M.A., Abbey, A., \& Jacques-Tiura, A.J. (2013). The relative importance of psychopathy-related traits in predicting impersonal sex and hostile masculinity. Personality and Individual Differences, 55, 817-822.

Lee, K., \& Ashton, M.C. (2006). Further assessment of the HEXACO Personality Inventory: Two new facet scales and an observer report form. Psychological Assessment, 18, 182-191.

Leistico, A.R., Salekin, R.T., DeCoster, J., \& Rogers, R. (2008). A large-scale meta-analysis relating the Hare measures of psychopathy to antisocial conduct. Law and Human Behavior, 32, 28-45.

Lynam, D.R. (2002). Psychopathy from the perspective of the five-factor model. In P.T. Costa, Jr., \& T.A. Widiger (Eds.), Personality disorders from the perspective of the five-factor model of personality, 2nd ed. (pp. 325-348). Washington, DC: American Psychological Association.

Mathieu, C., \& Babiak, P. (2015). Tell me who you are, I'll tell you how you lead: Beyond the Full-Range Leadership Model, the role of corporate psychopathy on employee attitudes. Personality and Individual Differences, 87, 8-12.

Međedović, J. (2011). Da li je amoralnost šesti faktor ličnosti? Zbornik Instituta za kriminološka i sociološka istraživanja, 30, 7-31.

Međedović, J. (2012). Topography of dishonesty: Mapping the opposite pole of honestyhumility personality domain. Primenjena psihologija, 5, 115-135.

Međedović, J. (2015). Nomološka mreža psihopatije. Beograd: Institut za kriminološka i sociološka istraživanja.

Međedović, J., \& Petrović, B. (2015). The Dark Tetrad: Structural properties and location in the personality space. Journal of Individual Differences, 36, 228-236.

Međedović, J., Petrović, B., Kujačić, D., Želeskov-Đorić, J., \& Savić, M. (2015). What is the optimal number of traits to describe psychopathy? Primenjena psihologija, 8, 109130.

Miller, J.D., Lynam, D.R., Widiger, T.A., \& Leukefeld, C. (2001). Personality disorders as extreme variants of common personality dimensions. Can the Five-factor model of personality adequately represent psychopathy? Journal of Personality, 69, 253-276.

Mokros, A., Osterheider, M., Hucker, S.J., \& Nitschke, J. (2011). Psychopathy and sexual sadism. Law and Human Behavior, 35, 188-199.

Neumann, C.S., Hare, R.D., \& Pardini, D.A. (2015). Antisociality and the construct of psychopathy: Data from across the globe. Journal of Personality, 83, 678-692. Advance online publication. doi: 10.1111/jopy.12127

O'Meara, A., Davies, J., \& Hammond, S. (2011). The psychometric properties and utility of the Short Sadistic Impulse Scale (SSIS). Psychological Assessment, 23, 523-531. 
Patrick, C.J., Fowles, D.C., \& Krueger, R.F. (2009). Triarchic conceptualization of psychopathy: Developmental origins of disinhibition, boldness, and meanness. Development and Psychopathology, 21, 913-938.

Paulhus, D.L., Neumann, C.S., Hare, R.D., Williams, K.M., \& Hemphill, J.F. (2016). SelfReport Psychopathy Scale 4th edition - technical manual. Toronto: Multi-Health Systems.

Petrović, B., \& Međedović, J. (2012). Alternativni pogledi na psihopatiju: Od patologije do adaptivne životne strategije. Zbornik Instituta za kriminološka $i$ sociološka istraživanja, 31, 19-48.

Porter, S., ten Brinke, L., \& Wilson, K. (2009). Crime profiles and conditional release performance of psychopathic and non-psychopathic sexual offenders. Legal and Criminological Psychology, 14, 109-118.

Raine, A. (1991). The SPQ: A scale for the assessment of schizotypal personality based on DSM-III-R criteria. Schizophrenia Bulletin, 17, 555-564.

Salekin, R.T. (2008). Psychopathy and recidivism form mid-adolescence to young adulthood: Cumulating legal problems and limiting life opportunities. Journal of Abnormal Psychology, 117, 386-395.

Skeem, J.L., \& Cooke, D.J. (2010). Is criminal behavior a central component of psychopathy? Conceptual directions for resolving the debate. Psychological Assessment, 22, 433-445.

Smederevac, S., Mitrović, D., \& Čolović, P. (2010). Velikih pet plus dva: Primena $i$ interpretacija [Big Five Plus Two: Manual for administration and interpretation]. Beograd, Serbia: Centar za primenjenu psihologiju.

Walton, K.E., Roberts, B.W., Krueger, R.F., Blonigen, D.M., \& Hicks, B.M. (2008). Capturing abnormal personality with normal personality inventories: An item response theory approach. Journal of Personality, 76, 1623-1648.

Witt, E.A., Donnellan, M.B., \& Blonigen, D.M. (2009). Using existing self-report inventories to measure the psychopathic personality traits of fearless dominance and impulsive antisociality. Journal of Research in Personality, 43, 1006-1016.

Witt, E.A., Hopwood, C.J., Morey, L.C., Markowitz, J.C., McGlashan, T.H., Grilo, C.M., ... Donnellan, M.B. (2010). Psychometric characteristics and clinical correlates of NEOPI-R fearless dominance and impulsive antisociality in the Collaborative Longitudinal Personality Disorders Study. Psychological Assessment, 22, 559-568. 


\section{Može li se pomoću HEXACO-PI-R-a adekvatno obuhvatiti četverofaktorski model psihopatije?}

\section{Sažetak}

U posljednje se vrijeme psihopatija pokušava mjeriti postojećim inventarima ličnosti. Cilj je ovoga rada istražiti može li se šestofaktorska struktura ličnosti (mjerena HEXACO-PI-R-om) upotrebljavati za procjenu modela psihopatije koji se sastoji od četiri crte: interpersonalne manipulacije, emocionalne hladnoće, eratičnoga životnog stila i antisocijalnih tendencija (mjerenih upitnikom SRP-4). U prvom su istraživanju (402 sudionika iz opće populacije) generirane zamjenske mjere ovih crta pomoću čestica HEXACO-PI-R-a. Pokazalo se da HEXACO-PI-R adekvatno objašnjava sve psihopatske crte izuzev antisocijalnih tendencija (svi su $R^{2}$ bili viši od .50). Zamjenske su mjere imale zadovoljavajuće pouzdanosti (svi su $\alpha$-koeficijenti bili viši od .70) i adekvatne korelacije s izvornim skalama psihopatije. Drugo (345 studenata preddiplomske razine) i treće istraživanje (245 osuđenika muškoga spola) pokazalo je diskriminativnu i vanjsku valjanost zamjenskih mjera. Ovi rezultati upućuju na to da se HEXACO-PI-R može upotrebljavati za istraživanje obilježja psihopatije koja uključuju interpersonalna, emocionalna i obilježja životnoga stila, što može olakšati daljnja istraživanja. Međutim, i dalje se preporuča korištenje inventara koji izravno mjere psihopatiju kad god je to moguće.

Ključne riječi: HEXACO-PI-R, četverofaktorski model psihopatije, procjena

\section{¿Puede HEXACO-IP-R representar adecuadamente el modelo de cuatro factores de la psicopatía?}

\section{Resumen}

Recientemente ha habido intentos de medir la psicopatía a través de los inventarios de personalidad existentes. El objetivo de esta investigación fue examinar si la estructura de seis factores de personalidad (medida por HEXACO-IP-R) se podría usar para evaluar el modelo de psicopatía que consta de cuatro rasgos: interpersonal, afectivo, de estilo de vida y antisocial (medidos por SRP-4). En el Estudio 1 (402 representantes de comunidad), la medida indirecta de estos rasgos se generó a través de los ítems HEXACO-IP-R. Se demostró que todos los rasgos de psicopatía (menos tendencias antisociales) se habían explicado adecuadamente por los rasgos HEXACO: todos los $R^{2}$ s eran $>.50$. La medida indirecta tuvo una fiabilidad satisfactoria (todos los Alphas $>.70$ ) y correlaciones adecuadas con las escalas originales de psicopatía. En el Estudio 2 (345 estudiantes universitarios) y Estudio 3 (245 condenados) se demostró la validez discriminativa y externa de la medida indirecta. Los resultados de esta investigación han demostrado que se podría usar HEXACO-IP-R para evaluar los rasgos de psicopatía interpersonales, afectivos y de estilo de vida, lo que podría facilitar las futuras investigaciones. Sin embargo, el uso de los inventarios que miden la psicopatía directamente es todavía preferible más que posible.

Palabras clave: HEXACO-IP-R, modelo de cuatro factores de psicopatía, evaluación

Primljeno: 14.10.2016. 
Appendix

\section{HEXACO-PI-R items used for the construction of the psychopathy scales}

Notes: the symbol $(R)$ suggest that the item is reversely coded; the names of HEXACO factors to which the items originally belong and their numbers in HEXACO-PI-R are provided in parenthesis as well

\section{Interpersonal:}

If I want something from a person I dislike, I will act very nicely toward that person in order to get it. (Honesty; no. 6)

My attitude toward people who have treated me badly is "forgive and forget". (R) (Agreeableness; no. 27)

I would be tempted to buy stolen property if I were financially tight. (Honesty; no. 36)

I would like to live in a very expensive, high-class neighborhood. (Honesty; no. 42)

I wouldn't want people to treat me as though I were superior to them. (R) (Honesty; no. 48)

If I want something from someone, I will laugh at that person's worst jokes. (Honesty; no. 54)

I would never accept a bribe, even if it were very large. (R) (Honesty; no. 60)

When people tell me that I m wrong, my first reaction is to argue with them. (Agreeableness; no. 63)

I would like to be seen driving around in a very expensive car. (Honesty; no. 66)

I think that I am entitled to more respect than the average person is. (Honesty; no. 72)

I find it hard to fully forgive someone who has done something mean to me. (Agreeableness; no. 75)

I wouldn't pretend to like someone just to get that person to do favors for me. (R) (Honesty; no. 78)

I'd be tempted to use counterfeit money, if I were sure I could get away with it. (Honesty; no. 84)

I would get a lot of pleasure from owning expensive luxury goods. (Honesty; no. 90)

I find it hard to keep my temper when people insult me. (Agreeableness; no. 93)

I want people to know that I am an important person of high status. (Honesty; no. 96)

People sometimes tell me that I'm too stubborn. (Agreeableness; no. 15)

If someone has cheated me once, I will always feel suspicious of that person. (Agreeableness; no. 51)

\section{Affective:}

People sometimes tell me that I am too critical of others. (Agreeableness; no. 9)

I avoid making "small talk" with people. (Extraversion; no. 16)

When I suffer from a painful experience, I need someone to make me feel comfortable. (R)

(Emotionality; no. 17)

I feel like crying when I see other people crying. (R) (Emotionality; no. 23)

I wouldn't spend my time reading a book of poetry. (Openness; no. 25) 
I can handle difficult situations without needing emotional support from anyone else.

(Emotionality; no. 41)

When someone I know well is unhappy, I can almost feel that person's pain myself. (R) (Emotionality; no. 47)

I feel that I am an unpopular person. (R) (Extraversion; no. 52)

I tend to be lenient in judging other people. (R) (Agreeableness; no. 57)

Whenever I feel worried about something, I want to share my concern with another person.

(R) (Emotionality; no. 65)

People often tell me that I should try to cheer up. (Extraversion; no. 70)

I feel strong emotions when someone close to me is going away for a long time. (R)

(Emotionality; no. 71)

Even in an emergency, I wouldn't feel like panicking. (Emotionality; no. 77)

I rarely discuss my problems with other people. (Emotionality; no. 89)

I remain unemotional even in situations where most people get very sentimental.

(Emotionality; no. 95)

I have sympathy for people who are less fortunate than I am. (R) (Altruism facet; no. 97)

I try to give generously to those in need. (R) (Altruism facet; no. 98)

People see me as a hard-hearted person. (Altruism facet; no. 100)

\section{Lifestyle:}

I would feel afraid if I had to travel in bad weather conditions. (R) (Emotionality; no. 5)

If I knew that I could never get caught, I would be willing to steal a million dollars.

(Honesty; no. 12)

I make decisions based on the feeling of the moment rather than on careful thought.

(Conscientiousness; no. 20)

People think of me as someone who has a quick temper. (Agreeableness; no. 21)

I plan ahead and organize things, to avoid scrambling at the last minute. (R)

(Conscientiousness; no. 26)

I don't mind doing jobs that involve dangerous work. (Emotionality; no. 29)

People often joke with me about the messiness of my room or desk. (Conscientiousness; no. 50)

I often push myself very hard when trying to achieve a goal. (R) (Conscientiousness; no. 32)

I make a lot of mistakes because I don't think before I act. (Conscientiousness; no. 44)

When it comes to physical danger, I am very fearful. (R) (Emotionality; no. 53)

Often when I set a goal, I end up quitting without having reached it. (Conscientiousness; no. 56)

I think of myself as a somewhat eccentric person. (Openness; no. 67)

I don't allow my impulses to govern my behavior. (R) (Conscientiousness; no. 68)

When working, I sometimes have difficulties due to being disorganized. (Conscientiousness; no. 74)

I do only the minimum amount of work needed to get by. (Conscientiousness; no. 80)

I prefer to do whatever comes to mind, rather than stick to a plan. (Conscientiousness; no. 92)

It wouldn't bother me to harm someone I didn't like. (Altruism facet; no. 99) 